\title{
sciendo
}

\section{IS METEOROLOGICAL EVIDENCE RELEVANT ENOUGH IN LEGAL DISPUTES? A ROMANIAN CASE STUDY.}

\author{
Ionac Nicoleta ${ }^{1}$, Tudor Ion ${ }^{2}$, Grigore Elena ${ }^{1}$, Constantin Dana ${ }^{1}$, \\ Uriţescu Bogdan ${ }^{1}$, Cică Roxana ${ }^{1,3}$
}

Key words: law dispute, meteorological evidence, force majeure clause.

\begin{abstract}
The increasing frequency and intensity of climate and weather extremes due to ongoing climate changes can cause major property and infrastructure damage. Mainly representing unforeseen and unavoidable hazards, some environmental and business laws broadly assimilate them as force majeure situations, excepting parties affected by their impact from prior commitments. The present study, debating on the way law courts should broadly address the force majeure clause when objective and accurate evidence is being provided, describes the terms of a legal dispute between the owners of two neighboring buildings which have seriously been damaged by a severe thunderstorm developing over the Bucharest-Otopeni town area, on the $22^{\text {nd }}$ July 2014. Consistent meteorological evidence (weather reports and forecasts, aerological diagrams, radar and satellite images, air-pressure distribution maps, synoptic messages etc.) have been presented to the law court to document, in an unbiased manner, on the extraordinary, external, unforeseen and unavoidable weather event representing the cause of a civil legal dispute. The extent to which the law court may take all these into consideration under the provisions of the force majeure clause is still to be explored.
\end{abstract}

\section{Introduction}

Nowadays, there is no further doubt that "trends in intensity and frequency of some climate and weather extremes have been detected over time spans ....based on several lines of evidence, including attribution studies for changes in extremes since 1950" (IPCC Report, 2018) and that these manifestations reveal "significant vulnerability and exposure of .... many human systems to current climate variability" (IPCC Report, 2014, p. 6), resulting that the rising rates of climate-related risks may trigger "abrupt and irreversible" detrimental consequences (IPCC Report, 2014, p. 13). The World Economic Forum has identified five top global risks currently

\footnotetext{
${ }^{1}$ University of Bucharest- Faculty of Geography. Bucharest. Romania: ionac.nicoleta@geo.unibuc.ro, ela_zigzag@hotmail.com, bogdan_uri@yahoo.com danamartines@yahoo.com.

${ }^{2}$ Lawyer’s Bar Bucharest, Romania: avocat_tudorion@yahoo.com

${ }^{3}$ National Administration of Meteorology, Bucharest, Romania: cicadianaroxana@yahoo.com
} 
impacting global economy in the coming ten years, four of them being climate change - related (namely: extreme weather events and temperatures; accelerating biodiversity loss; pollution of air, soil and water; failures of climate-change mitigation and adaptation) (Global Risks Report, 2018). They are broadly defined as "uncertain events or conditions that, if occurring, can cause significant impact", including major property and infrastructure damage, with "every risk in the category lying in the higher-impact, higher-likelihood quadrant" (Global Risks Report, 2017).

Consequently, the extent to which the climate change-related events may represent unforeseen and unavoidable forces, as main attributes of force majeure situations, is still to be explored. Literally, force majeure means "superior force" and there is no universal definition of what a force majeure event might represent, although, in business and industry terms, it refers to any "unavoidable event beyond the reasonable control of a party" (McCarthy Tétrault LLP, 2018). In many environmental and business laws, some natural causes or force majeure provisions except parties from their prior commitments, because of factors outside their control. In some, climate change is viewed as a "large exogenic unmanaged pressure in that it emanates from outside the area being managed..." (Elliot M. et al., 2015), accordingly suggesting that a defence by a member of "force majeure may be accepted if an event was proven to be due to an externality of control, irresistible and unforeseeable". In short, a force majeure clause may simply "discharge a contracting party when a supervening, sometimes supernatural, event, beyond control of either party" provokes disruptions and failure of contracts (Saul R., Barnes R., Elliot M., 2016). In this respect, the ICC Force Majeure Clause 2003 (known as the "The ICC Clause") outlines, in paragraphs 1 and 4 , the general agreed-upon features of a force majeure formula which may exonerate a party from its legal or contractual duties: (1) event caused by impediments beyond reasonable control, (2) impossibility of reasonably expecting the occurrence of the event in a specific location and at a specified time; (3) event whose effects could not reasonably been avoided or overcome (ICC Force Majeure Clause 2003), also listing, in paragraph 3, a series of possible force majeure situations, including:"Act of God, plague, epidemic, natural disaster such as but not limited to violent storm, cyclone, typhoon, hurricane, tornado, blizzard, earthquake, volcanic activity, landslide, tidal wave, tsunami, flood, damage or destruction by lightning, drought".

Actually, all these represent, in fact, various potential outcomes of what the climate change effects are considered to be, demonstrating that, as weather and climate science develop and new, modern and more accurate means of measurement and observation are being used, the force majeure events should be addressed on courts and tribunals from a wider perspective in terms of their unforeseeable occurrence, severity and spatial extent, depending on how the driving forces or causes of a specific weather or climate risk event can objectively be documented. Broadly, this is the contextual 
framework of the present study, discussing the relevance of meteorological evidence in a legal dispute calling forth the force majeure clause.

\section{Case study : Civil law case 12615/94/2014* - Buftea Law Court - Ilfov County}

The owners of the building located in Otopeni, Bucharest Driveway no. 40 Ilfov County, sue the owners of their neighboring building (located in Otopeni, Bucharest Driveway no. 36 - Ilfov County) (Fig. 1), complaining that, during a violent storm that developed in the area, on the $22^{\text {nd }}$ of July 2014, some loose parts were blown away from the rooftop of the latter building and were projected into the glass-framed walls of their own building, breaking off some of its tempered glass windows, the initial damage being estimated to only some thousand EUROs. The claimant pretends that his loss is due to a construction flaw of the neighboring building rooftop (located at no. 36) causing some loose fragments of construction materials to be easily blown away and projected directly into the exposed glas-windowed walls and roof of his own building (Fig. 2). Based on the photographs which the claimant included in his law file to document the damage, despite the fact that they were taken after a period of a year and a half after the event had actually taken place, as well as on the documents certifying the remedial and repair costs, which have nonetheless been made about three years and a half after the weather event had been produced, the claimant mounted his financial compensations to a much higher value, to which consistent penalties and interests would accordingly be added up.

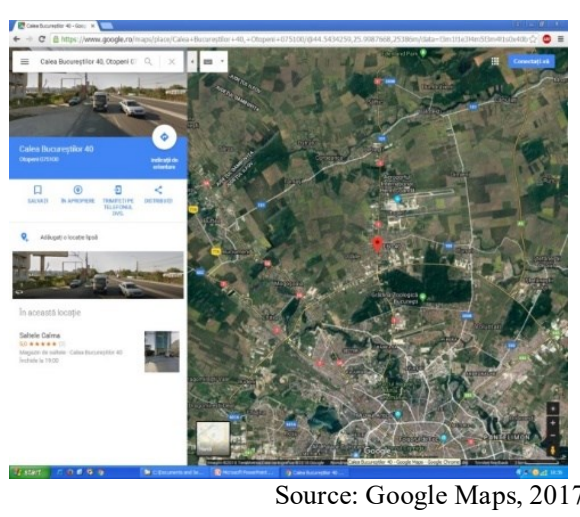

Fig. 1. Geographical location of the buildings affected by the storm on $22^{\text {nd }}$ July 2018

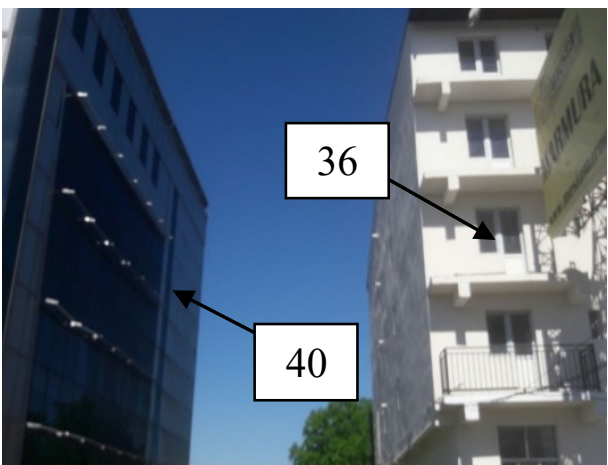

Fig. 2. General view of the two neighboring buildings affected by the storm on the $22^{\text {nd }}$ July 2018

The claimant justified his request for summons to judgment on the provisions of Art. 1376 and follow-ups in the Romanian Civil Law Code, stating that 
"prejudices/damages caused by a building which had ruined / been degraded because of some construction flaws or improper maintenance are excepted from the enforcement of the (respective) dispositions". Actually, the state of the matter called upon by the claimant, referring to the existence of a presumable construction flaw which made loose parts from the neighboring rooftop (no. 36) be blown away into the building he owns (no. 40), are explicitly included in the provisions of Art. 1378 Civil Code, regulating the liability conditions for any building ruin situation: "The owner of a building or construction of any kind is compelled to repair the damage caused by its state of ruin or by loose parts disconnected from them, provided that these facts represent a consequence of improper maintenance or a construction flaw" and in the provisions of Art. 1388 Civil Code, exactly regulating the conditions in which damages due to building ruin or improper maintenance are imposed. This means that: 1) the claimant justified his legal request on inadequate law grounds (Art. 1376 instead of 1388) and 2) in both cases (Art. 1376 and 1378), the defendants are excepted from legal responsibility simply because the conditions for misdemeanor civil responsibility are not met because:

a) The claimant has to demonstrate the unlawful action consisting in the pre existence of a construction flaw, this representing an essential condition to justify legal action. No evidence in the file, including the expert's report, has clearly established that the defendants' building could have had any construction flaw, otherwise, in the absence of such an important piece of evidence, the defendants cannot be accused of something which has not actually existed and, therefore, they cannot be made responsible for any unlawful deed. On the contrary, the defendants have brought to court evidence certifying that their building (no. 36) could not have any construction flaw as it had been designed and built according to all existing technical norms and construction quality and safety standards, entirely certified by documents and photographs taken during different construction phases. However, the claimant did not document on the movement dynamics / trajectory / direction of the defendant's rooftop loose parts that supposedly hit his building.

b) The defendants have provided sound proofs demonstrating that their rooftop did not actually hit the neighboring building as the weather hazard that really damaged the claimants' building (a violent storm) developed strong wind currents blowing various other flying objects/things from the back of the two adjoining buildings, meaning that the glass walls of the claimants' building could have been broken by loose rooftop parts being pulled out from the defendants' building only if winds had blown perpendicular to the two buildings having about the same height, which was not the case, because:

-according to the explanatory notes made by the National Meteorological Administration and the University of Bucharest (Meteorology and Hydrology Dept.) (pp. 971-989, vol. IV, law court file) and all the other evidence that the defendants provided, there is no doubt that strong air currents blew from the open- 
space field lying at the back of the two buildings, right through the narrow space in-between them, thus creating a canyon-like effect which led to an extreme convergence of air-currents and increased wind-speeds, and finally across the bordering national road no. 1 (DN 1);

- according to the Minutes of Intervention for Extrication no. 32/22.07.2014, made by the Inspectorate for Emergency Situations in Bucharest-Ilfov, on the day of the violent weather event (storm), various loose parts from construction materials (tiles, bricks, etc. including fragments from the defendants' rooftop cover) and tree branches have been blown away by an exceptionally strong gale all over the places across the DN 1 which accordingly had to be blocked for road traffic until local intervention forces removed them and cleared the driveway. This also points to the fact that, at that moment, the wind was blowing along or, in other words, in-between, and not perpendicular to, the two buildings aligning perpendicular to the main DN 1 road, also indicating that the winds associated to the extreme weather event could have blown away loose parts pulled out from other neighboring houses as well;

-according to the construction expert's notes (pp. 6 on Expert Report), "it is not to be excluded that other types of loose materials (trees, bricks, branches etc.) could have been carried away by the thunderstorm as well, consequently producing the denounced damages...";

- according to the legalized testimony of the D.N. eyewitness (Declaration no. 295/16.05.2017) (pp. 547-549, vol. II, law court file) which lived the exceptional weather event on the 22.07.2014 (making him seek shelter indoors the defendant's building), strong whirlwinds blowing from the field area at the back of the two buildings, were channeled in-between them, greatly increasing wind-speeds and pulling out various things from neighboring houses alongside their track; ultimately projecting them down, on the DN 1 driveway, as the gale was calming down. As result, in the aftermath of the violent storm, the road traffic on DN 1 had to be stopped for intervention forces to clear away debris. However, what's most interesting is the fact that neither the construction expert, nor any other eye-witness could testify that the rooftop of the defendants might have actually broken down the glass-windowed walls of their neighboring building during the violent weather phenomenon as the storm-eye path (as the eye-witness compared the respective weather event to a tornado) was oriented along and not across the two buildings;

- according to the specialty notes submitted by the University of Bucharest (Meteorology-Hydrology Dept.) (pp. 971-989, vol. IV, law court file), there is absolutely true that: "on the 22th of July 2014, between 17.00 - 19.00 local time, the wind speed recorded at the Otopeni (Ilfov county - Romania) weather station mounted to exceptionally high gust values (more than $38 \mathrm{~km} / \mathrm{h}$ ). Moreover, the corresponding aerological diagrams also show a marked increase of wind-speeds and significant sudden changes of wind direction up to a height of $86 \mathrm{~m}$ above the ground, which 
actually compose the picture of a violent thunderstorm accompanying whirlwinds blowing aside the two buildings and perpendicular to the DN 1 . This is why, due to the counter-clockwise rotation of the winds, from $\mathrm{E}$ to $\mathrm{W}$, perpendicular to the DN 1, oriented on a N-S direction, loose rooftop parts from the defendants' building, as high as $10.90 \mathrm{~m}$, could not have been projected into the neighboring glass-walled building, as high as $25.22 \mathrm{~m}$, simply because they were both oriented along, and not across, the E-W air currents lines flowing quite in-between them, right across the DN1.

\section{The meteorological context for which force majeure circumstances are} appealed

On the afternoon of $22^{\text {nd }}$ July 2014, an extreme weather phenomenon looking like a mesocyclone produced serious direct damages to several buildings in Otopeni town area (Ilfov county). This extraordinary atmospheric event, although small-scale spatially restricted, could objectively be demonstrated by various types of evidence, issued by institutions with legal and professional authority in the field:

1. The National Administration of Meteorology, representing the most representative authority on weather monitoring and forecasting in Romania, has clearly revealed that the extreme weather event developing over the northern part of Bucharest city area (with Otopeni town included) had all the specific traits of a MESOCYCLONE, according to addresses no. 2750/21.07.2015 (pp. 169); no. 5961/23.11.2017, pp. 2 - "Meteorological data recorded on 22.07.2014, between 17.30-20.00 local time, at Bucharest-Băneasa weather station" (the nearest standard weather station) (pp. 865, 832, verso, vol. IV; 1094-1095, vol.V law court file) and the accompanying radar images (pp. 867-888, vol. IV, law court file). The first one of these official addresses states that: ,from 9.00 A.M. on the 22nd of July 2014 to 9.00 A.M. on the 23rd July 2014, the meteorological conditions in the area of the Bucharest-Băneasa weather station were characterized by: cloudy skies, heavy rainfalls reaching a total of $7.4 \mathrm{l} / \mathrm{sq}$. $m$ accompanied by lightning and strong winds with speeds up to $19 \mathrm{~m} / \mathrm{s}$ (equivalent to $68.4 \mathrm{~km} / \mathrm{h}$ ) during wind gusts". On the given circumstances, a yellow code nowcasting warning was issued for immediate dangerous meteorological phenomena anticipated to develop between $18.00-19.00 \mathrm{hrs}$. local time, on the eastern and northern regions of the Bucharest metropolitan area. Most intriguing about this nowcasting warning is the fact that it actually highlighted the unforeseeable character of the weather phenomenon, provided that the European Storm Forecast Experiment (ESTOFEX) forecast for the same day pointed to only some probable minor meso-scale atmospheric disturbances over the Alps between 13.00-18.00 UTC (15.00-20.00 local time).

2. The Meteoblue A.G company in Basel also informed, on the $15^{\text {th }}$ Nov. 2016, on request (pp. 659-660, vol. III law court file), that, on the $22^{\text {nd }}$ of July 2014 (18.00$19.00 \mathrm{hrs}$. local time), the Otopeni town area was affected by: "a sharp air-temperature 
drop (from $32^{\circ} \mathrm{C}$ at 18.00 to $25^{\circ} \mathrm{C}$ at 19.00) as result of a rapid adiabatic cooling of ascending air-masses; a sudden increase of rainfall amounts (from $0.5 \mathrm{~mm}$ at 18.00 to over $0.9 \mathrm{~mm}$ at 19.00, indicative of heavy showers and an extraordinary increase of wind speed between 19.00-21.00 hrs. local time, with gusts reaching as high as $38 \mathrm{~km} / \mathrm{s}$ (= over $10 \mathrm{~m} / \mathrm{s}$ )"; all manifestations pointing to adverse weather conditions of a severe thunderstorm that might easily uproot trees and blow away rooftops (according to the nature and specific manifestations of windstorms of certain intensity).

3. The aerological (skew-T log) diagrams interpreted in a report completed by the University of Bucharest, indicate very unstable atmospheric conditions in the area of the Bucharest-Băneasa weather station from 22.07.2014 - 12.00 UTC to 23.07.2014 00.00 UTC, because of the rapid and forced ascent (convection) of an extremely hot and humid air-parcel (with air-temperatures higher than $35^{\circ} \mathrm{C}$ and water vapour mixing ratio values exceeding $32 \mathrm{~g} / \mathrm{kg}$ at the height of $80 \mathrm{~m}$ above the ground) (Fig. 3).

The extremely unstable atmosphere is also reflected by the values of the corresponding indices of atmospheric instability (on the right side of the diagrams):

- Showalter Index - SHOW: -0.71 (at 12.00) and -2.46 (at 00.00) - SHOW values ranging from 0 to -3 indicating thunderstorm with hailstones;

- Lifted Index - LIFT: -1.50 (at 12.00) and -1.92 (at 00.00) - LIFT values lower than -1.50 indicating extremely unstable weather conditions;

- SWET convection Index - SWET: 186.9 (at 12.00) and 239,1 (at 00.00) SWET values ranging between 200 and 300 units indicating storm conditions;

- Total Total Index - TOTL: 47.70 (at 12.00) and 51.60 (at 00.00) - TOTL values higher than 45 units indicating medium-intensity storms.
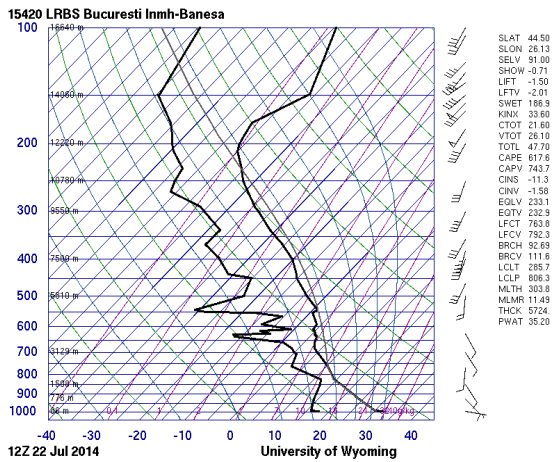
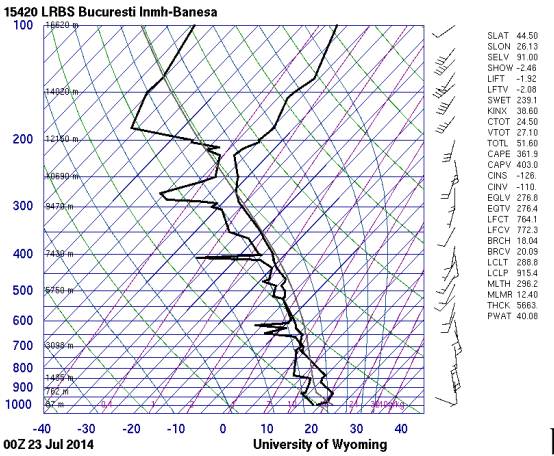

Source: University of Wyoming, 2016

Fig. 3. Aerological diagrams of atmosphere's vertical profile at Bucharest-Băneasa weather station on 22.07.2014 - 12.00 UTC. (a) and 23.07.2014 - 00.00 UTC (b).

The unstable weather conditions also determined increased wind shears and velocities: 
- The wind-shear on the 22.07.2014 - 12.00 UTC is represented by the sudden and radical change of wind direction in the lower layers of the atmosphere, not higher than $80 \mathrm{~m}$, where winds blowing on an E-W direction instantly shifted to a SE-NW direction, extending into a rotational air-column up to the higher levels of the atmosphere;

- The wind intensity rapidly grew from speed values of $1.5-3.5 \mathrm{~m} / \mathrm{s}$ above ground level, to values higher than $24-26 \mathrm{~m} / \mathrm{s}$ towards the upper atmosphere, ocasionally reaching powerful wind gusts of more than $24-26 \mathrm{~km} / \mathrm{h}$ at ground level.

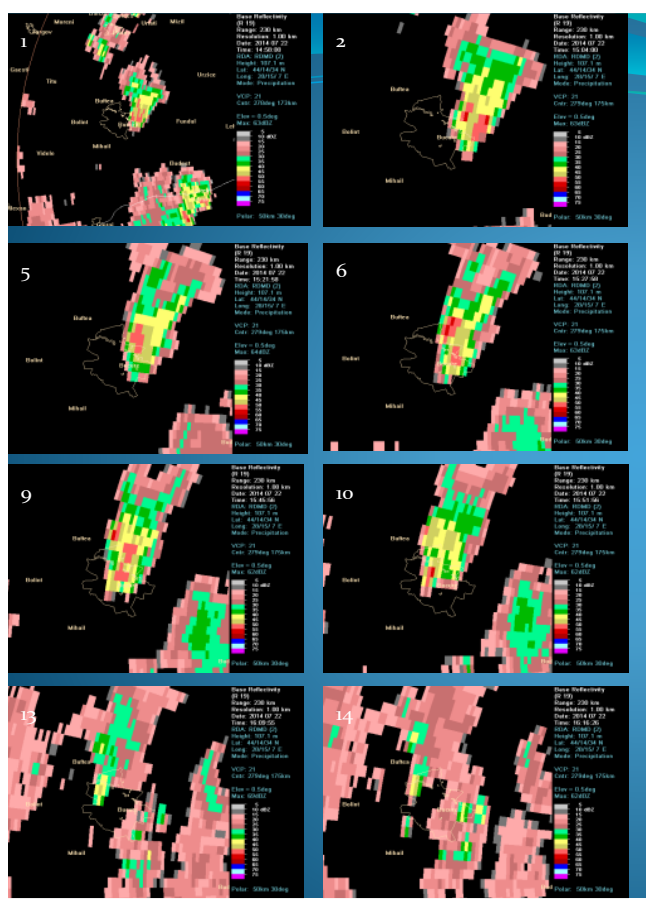

Fig. 4. Radar images of the convective storm clouds over the $\mathrm{N}$ and NW parts of the Bucharest metropolitan area, on 22.07.2014.

4. The radar images captured by the National Administration of Meteorology for the surrounding areas of the Bucharest-Băneasa weather station, from 22.07. 2014 $14.58 \mathrm{hrs}$. local time to 23.07 .2014 - $16.46 \mathrm{hrs}$. local time (pp. 867-877, vol. IV, law court file) fully confirm the highly unstable atmosphere over the $\mathrm{W}$ and NW regions of the Bucharest metropolitan area (Fig. 4), showing, in an extended reading (pp. 878888 , vol. IV, law court file), that the thermodynamic ascending convection of the hot, moist air-parcel was so powerful as it was forcefully pushed upwards at altitudes 
higher than $16.000 \mathrm{~m}$, that the radar echoes reached peak intensities exceeding $64 \mathrm{dBz}$, indicative of thunderstorm-related Cumulonimbus clouds, with heavy water content.

In its extended explanatory note (Address no. 5961/23.11.2017, pp. 2 "Meteorological data recorded on 22.07.2014, between 17.30-20.00 local time, at Bucharest-Băneasa weather station") (pp. 865, 832, verso, vol. IV; pp. 1094-1095, vol.V law court file), the National Administration of Meteorology demonstrates that the weather phenomenon affecting the Bucharest - Otopeni town area on 22.07.2014, from 18.00 to 19.00 local time $(=16.00-17.00 \mathrm{UTC})$, was represented by a mesocyclone with a high-reflectivity core area, around which counter-clockwise rotational winds determined intense up- and down-drafts producing wind-shears and wind-gusts. This extremely unstable whirlwind nucleus in the central part of a larger convective system, initially developed in the SE parts of the Bucharest metropolitan area, then moved to the E-NE-N-NW, where, due to frictional forces with the wooded ground surfaces, it was eventually forced to calm down and dissipate, not before playing havoc on the N and NW parts of the reference area. Meteorologically, the mesocyclone is an extremely violent and also rare type of super-cell storms that powerful thermo-convective Cumulonimbus systems can create, so that its forecast is rarely possible earlier than $30 \mathrm{mins}-1 \mathrm{hr}$. before its onset and development. So, on these conditions, the main question is: Could such a phenomenon possibly be considered a meteorological norm or, on the contrary, an extraordinary, unpredictable, unforeseeable and invincible event, that is a force majeure case?

\section{Meteorological evidence for the 22.07.2014 unforeseeable \\ thunderstorm}

The evolution of weather conditions on the 22nd of July 2014 from $15.00-17.00$ UTC ( $=17.00-19.00 \mathrm{hrs}$. local time) indicate the presence of a convective super-cell system moving counter-clockwise, over the NE-N parts of the Bucharest town area:

1) The radar images taken by the WSR-98D radar located in Medgidia (scan elevation of $0.5^{\circ}$ ) clearly define, on the reflectivity field, the V-like form of the supercell storm which is backwardly affected by the forward flank downdraft - FFD) (Fig. 5).

2) The field of relative Doppler velocities can best reveal whether there was a cyclonic (counter-clockwise) rotation of winds in the area of maximum radar reflectivity. As fig. 6 shows, this field displays a bipolar coupling zone (relatively oval zones with adjoining positive and negative Doppler velocities) indicating the cyclonic/counter-clockwise rotation of cloud systems and a strong convergent movement aloft, due to the presence of the FFD in the area of interest.

3) The maximum reflectivity values on air columns obtained from all scan elevations (10 elevations for Bucharest) also reveal a sudden increase in the area of interest, from 15.30 UTC to 15.48 UTC, followed by a rapid decrease around 15.54 
UTC, meaning that a rapid air downdraft quickly transported raindrops and hailstones to the ground surface, thus intensifying wind-speeds near earth ground (Fig. 7).
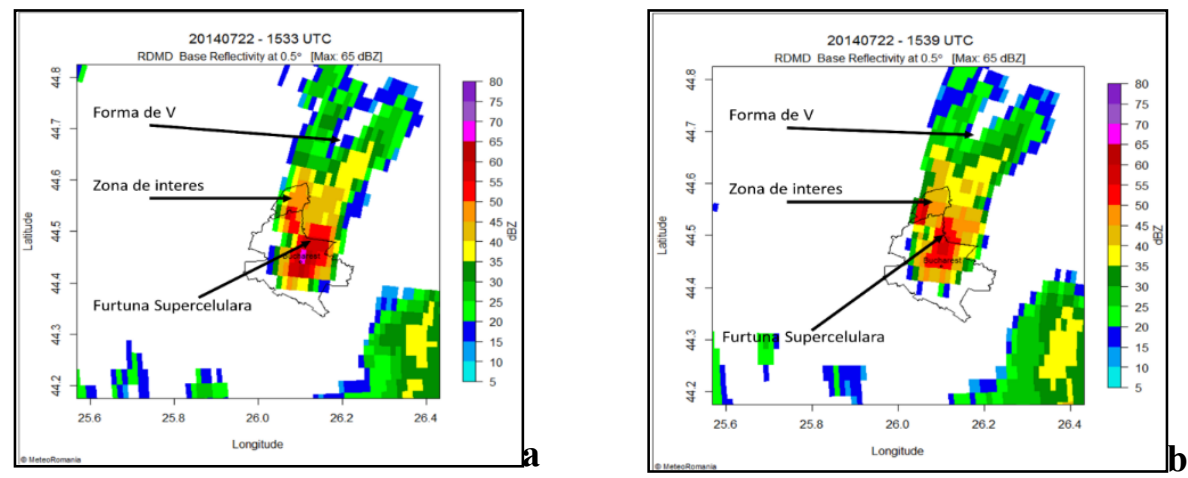

Source: ANM, 2017

Fig. 5. The radar reflectivity field on the NW parts of Bucharest metropolitan area, on 22.07.2014 at 15.33 UTC (a) and 15.39 UTC (b).

4) The additional research work made by a team at the University of Bucharest (pp. 971-989, vol. IV, law court file) on the development of the intense mesocyclone in the area of the Bucharest-Băneasa weather station (Ilfov county, Romania - OMM code: 15420; ICAO code: LRBS; Lat. 44:30:38N, Long. 26:04:41E, Alt. $91 \mathrm{~m})$, on the afternoon of the $22^{\text {nd }}$ July 2014 (18.00 - 21.00 local time $=$ UTC +3$)$, also demonstrates that the powerful thunderstorm that it produced could be considered as an external/exogenic, unforeseeable, invincible and unavoidable event roughly describing a force majeure situation:
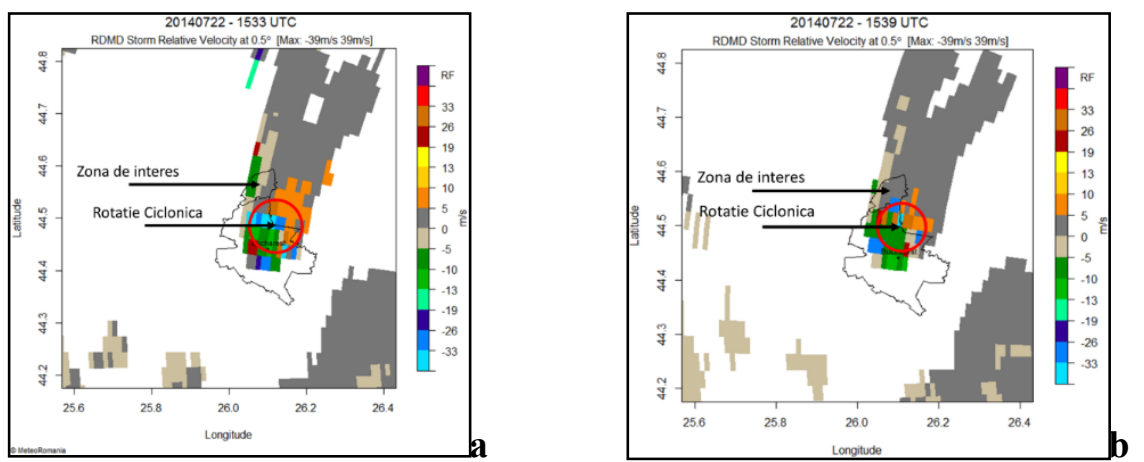

Source: ANM, 2017

Fig. 6. The field of Doppler velocities in the convective cloud system developing over the NW parts of Bucharest metropolitan area, on 22.07.2014 at 15.33 UTC (a) and 15.39 UTC

(b). 
- The GFS reanalysis maps for the pressure field at $500 \mathrm{hPa}$ indicate the presence, in the SE parts of the country, of a large high-pressure area $(1010 \mathrm{hPa})$ with very stable conditions, meaning that, at the ground level, the air was highly unstable, especially that the geopotential energy values constantly maintained between $576 \mathrm{dm}$ (at $12.00 \mathrm{UTC}$ ) and $584 \mathrm{dm}$ (at 18.00 UTC) (Fig. 8).

- The relatively stable atmosphere at the $500 \mathrm{hPa}$ level is also obvious on the earthground synoptic maps (Fig. 9), where no atmospheric fronts or disturbances are present in the area of reference, on 22.07.2014-00.00 UTC to 23.07.2014-00.00 UTC, meaning that the violent storm under debate was not caused by any general dynamics factors, but by extremely intense thermo-convective processes, with rapid and unexpected development.

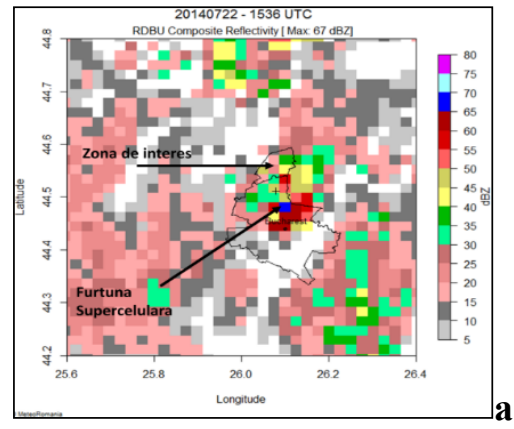

Fig. 7. Maximum reflectivity values on air columns in the convective cloud system developing over the NW parts of Bucharest metropolitan area, on 22.07.2014 at 15.36 UTC (a) and 15.48 UTC (b).

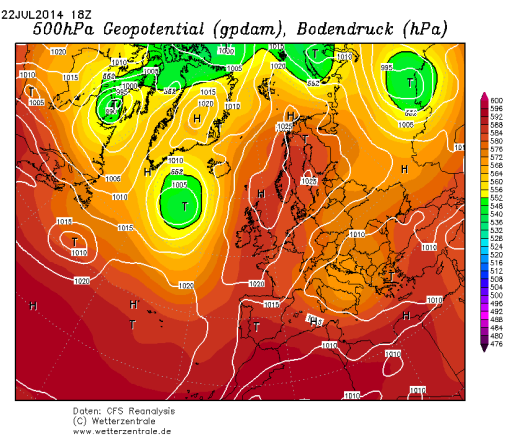

Fig. 8. Map of pressure field $(\mathrm{hPa})$ and geopotential heights (gpdm) at $500 \mathrm{hPa}$ level, over Europe, on 22.07.2014-18.00 UTC.

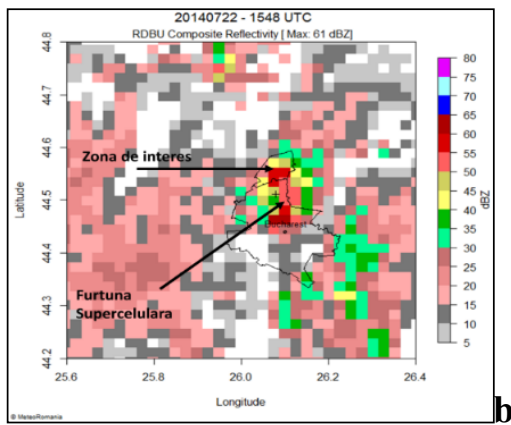

Source: ANM, 2017

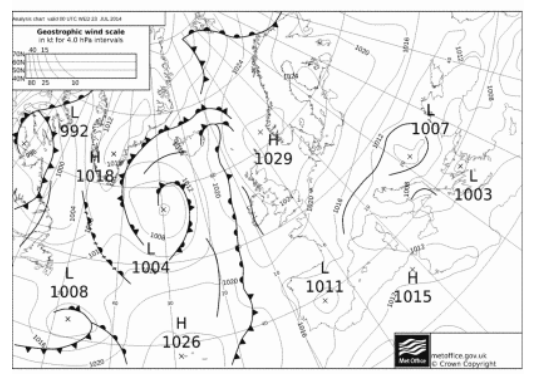

Fig. 9. Map of pressure field $(\mathrm{hPa})$ and atmospheric fronts at the ground level, over Europe, on 23.07.2014-00.00 UTC.

Source: Wetter Zentrale and UK Met, 2017 
- The high-resolution satellite images transmitted by the MODIS sensor of the NASA-operated AQUA satellite, on 22.07.2014, indicate the presence of a large, isolated thermo-convective cloud-system (Cumulonimbus) in the clear skies dominating Romania's SE parts, accordingly reflecting very unstable weather conditions that might have produced rapid wind-speed increase, heavy rainfall, lightning and violent thunderstorm (Fig. 10).

- The METAR messages (used to swiftly transmit weather information relevant for aviation) also show that a large Cumulonimbus cloud developed in the BucharestBăneasa area between 15.00-15.30 UTC, followed by heavy showers (16.00) which stopped around 16.30, as the thermo-convective system shifted over the BucharestOtopeni area, located a little farther to the N (Fig. 11).

- Moreover, the same-day SYNOP meteorological information reveals that wind gusts recorded at Bucharest-Băneasa reached maximum speed values of $68.4 \mathrm{~km} / \mathrm{h}(=19.0$ $\mathrm{m} / \mathrm{s})$ at 17.00 UTC whereas the normal wind speed was only $10.8 \mathrm{~km} / \mathrm{h}(=3,0 \mathrm{~m} / \mathrm{s})$.

\section{Conclusions}

The severe weather conditions on the late afternoon of 22nd July 2014, characterized by an intense mesocyclone that caused an exceptionally high $(16,000$ m) thermo-convective Cumulonimbus-cloud system to develop over the BucharestOtopeni town area, producing a violent thunderstorm with powerful whirlwinds, heavy showers and lightning, can essentially be described as an external, unforeseen and unavoidable phenomenon, according to the most proper meaning of the Art. 1351 paragraph (2) provisions in the Romanian New Civil Code, because:

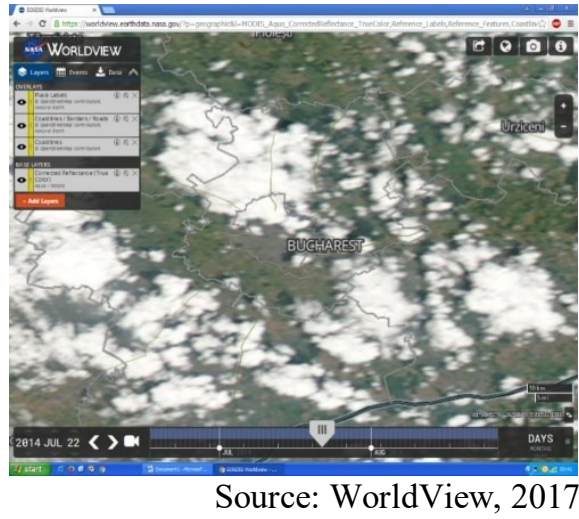

Fig. 10. Satellite image (visible) over SE Europe, on 22.07.2014.

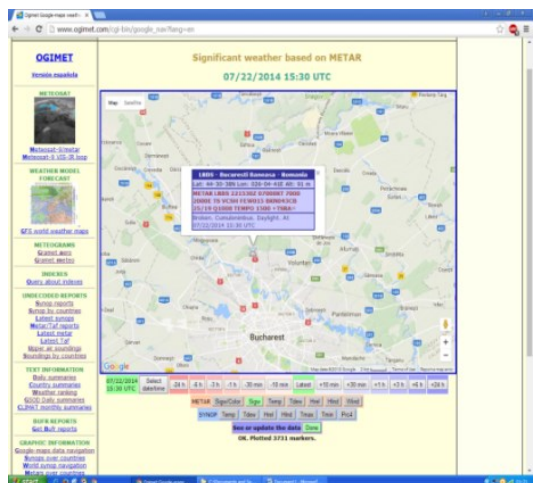

Source: Ogimet, 2017

Fig. 11. The METAR warning message for Bucharest-Băneasa, on 22.07.2014, 15.00 UTC 
- All weather conditions have resulted from an external, exogenic atmospheric force determining rapid and sudden thermo-dynamic transformations of extremely unstable air-parcels which could not have been satisfactorily anticipated in the context of a generally stable open atmosphere;

- The resulting meteorological phenomena (violent thunderstorm-related hazards) were totally unexpected and therefore, highly unavoidable and invincible, since they were caused by almost instantly energy transformations that could, under no circumstances, be efficiently predicted and consequently, mitigated with;

- The spontaneous development of the adverse meteorological conditions had an unanticipated impact, as described by the force majeure provisions of the law. But it remains for the law court to decide whether and to what extent the meteorological evidence is proof-solid enough to justify for this kind of sentence...

\section{References}

Elliot Michael, Borja Angel, McQuatters Abigail, Mazik Gollop Krysia, Birchenough Silvana, Andersen Jesper H., Painting Suzanne, Peck Myron (2015) Force majeure: Will climate change affect our ability to attain Good Environmental Status for marine biodiversity? Marine Pollution Bulletin, Volume 95, Issue 1, Elsevier Pub. House, Pages 7-27.

International Chamber of Commerce (2003) "ICC Force Majeure Clause 2003, ICC Hardship Clause 2003", online: https://iccwbo.org/publication/icc-force-majeureclause-2003icc-hardship-clause-2003/ ("ICC Clause").

IPCC (2018) Summary for Policymakers. In: Global warming of $1.5^{\circ} \mathrm{C}$. An IPCC Special Report on the impacts of global warming of $1.5^{\circ} \mathrm{C}$ above pre-industrial levels and related global greenhouse gas emission pathways, in the context of strengthening the global response to the threat of climate change, sustainable development, and efforts to eradicate poverty [V. Masson-Delmotte, P. Zhai, H. O. Pörtner et al.(eds.)]. World Meteorological Organization, Geneva, Switzerland, pp. 6.

IPCC (2014) Climate Change 2014: Synthesis Report. Contribution of Working Groups I, II and III to the Fifth Assessment Report of the Intergovernmental Panel on Climate Change [Core Writing Team, R.K. Pachauri and L.A. Meyer (eds.)]. IPCC, Geneva, Switzerland, pp. 6 and 13.

Lee-Andersen Selina, Seaborn Claire and West Andrew (2018) Impacts of climate change - foreseeable or unforeseeable? Drafting force majeure clauses in the era of climate uncertainty, https://www.mccarthy.ca/en/insights/blogs/canadian-eraperspectives/ , McCarthy Tétrault LLP: accesed on: 22 september 2018.

Saul Roxanne, Barnes Richard, Elliot Michael (2016) - Is climate change an unforeseen, irresistible and external factor - A force majeure in marine environmental law?, Marine Pollution Bulletin, Volume 113, Issues 1-2, Elsevier Pub. House, p. 25-35.

World Economic Forum (2018) Global Risks Report, 13 ${ }^{\text {th }}$ Edition, Geneva, page 11.

World Economic Forum (2017) Global Risks Report, 12 ${ }^{\text {th }}$ Edition, Geneva, page 16. 
128 Ionac Nicoleta Tudor Ion, Grigore Elena, Constantin Dana, Urițescu Bogdan, Cică Roxana

www.weather.uwyo.edu/upperair/sounding, www.wetter3.de, www.ogimet.com, www.worldview-earthdata.gov, accessed on 14 June 2016. 